\title{
How Shopping Frequency And Product Type Affect Consumers' Perceptions Of E-Tailing Quality
}

Rose Sebastianelli, (Email: sebastianer1@scranton.edu), University of Scranton Nabil Tamimi, (Email: tamimin1@scranton.edu), University of Scranton Murli Rajan, (Email: Murli.Rajan@scranton.edu), University of Scranton

\begin{abstract}
We survey a national sample of US online consumers about their perceptions regarding the quality of online shopping experiences. Our intent is to examine whether the frequency with which they purchase products online and the types of products they purchase affect their perceptions of internet retailer quality. In this study, the quality of online shopping is measured using a set of items that represent the four phases encountered when shopping via the Internet: (1) the retailer's homepage, (2) online product catalog, (3) order form and (4) customer service and support. Factor analysis of these items uncovers the following seven underlying e-tailing quality dimensions: reliability, accessibility, ordering services, convenience, product content, assurance and credibility. We find that frequent online shoppers consider both reliability and product content significantly more important than infrequent online shoppers; ordering services is significantly more important to infrequent online shoppers. With regard to product type, we find some significant differences between online shoppers who purchase "search" versus "experience" products. Specifically, those who purchase experience products online rate ordering services and product content significantly more important than those who buy search products.
\end{abstract}

\section{INTRODUCTION}

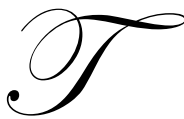

he growth in e-commerce has been extraordinary, with many of today's business transactions being conducted through the Internet. The volume of online business-to-consumer (B2C) transactions continues to rise. In the U.S., online holiday sales for 2004 totaled $\$ 23.2$ billion, a $25 \%$ increase over the same period in 2003. Online shoppers spent $\$ 3.8$ billion on clothing / apparel. Toys and video games accounted for $11 \%$ ( $\$ 2.5$ billion) and consumer electronics for $10 \%$ ( $\$ 2.3$ billion) of the total (Shop.org statistics; E-business trends). Given this tremendous growth and greater dependence on e-commerce, determining what makes a quality shopping experience for online consumers has become increasingly important for firms attempting to meet customer expectations and stay competitive in the virtual marketplace.

Improved quality has long been recognized as a means to increase profitability of the firm and ensure its long-run survival in a constantly changing business environment (Deming, 1986). From Total Quality Management (TQM) to newer initiatives such as Six Sigma, firms continue to implement quality improvement programs in their efforts to increase profitability and attain higher levels of customer satisfaction. It is not surprising, then, that practitioners and researchers alike have turned their attention to issues related to improving the Internet shopping experience.

In this paper, we examine whether the frequency with which consumers purchase products online and the types of products they purchase affect their perceptions of internet retailer quality. These questions are addressed in the context of a larger scale study designed to identify critical dimensions of e-quality. 


\section{E-Quality Dimensions}

Several researchers have concentrated on identifying the dimensions of e-quality. For example, Cox and Dale (2001) used service quality dimensions as a reference point and determined that some apply to the online experience. These include accessibility, communication, credibility, understanding and appearance. But perhaps the most comprehensive framework for e-quality has been proposed by Madu and Madu (2002). Borrowing dimensions from both product and service quality, they identify the following 15 dimensions: (1) performance - ease of use and accuracy of content on website; (2) features - extras such as links to other sites; (3) structure - organization of website; (4) aesthetics - visual attractiveness of website; (5) reliability - consistency of website performance; (6) Storage capability - ease of information retrieval; (7) serviceability - how well customer complaints are resolved; (8) security and system integrity - ability to safeguard and protect confidential information; (9) trust - affects willingness of users to disclose personal information or make purchase decisions; (10) responsiveness - prompt response to customer concerns; (11) product/service differentiation and customization - unique services provided by the website; (12) web store policies - customer-oriented; (13) reputation - exceed the performance expectations for the users; (14) assurance - impeccable e-mail service for direct communication; and (15) empathy - providing individualized attention. This conceptual framework includes dimensions of product quality, service quality as well as some that are unique to virtual operations.

Closely related to e-quality is the issue of satisfaction among e-commerce users and consumers. The link between quality and customer satisfaction has been well documented in the literature (e.g., Cronin and Taylor, 1992). In developing an e-commerce user-consumer satisfaction index, Cho and Park (2002) considered a number of factors related to e-quality. These include product information, customer service, purchase result and delivery, site design, purchasing process, product merchandizing, delivery time and charge, payment methods, ease of use, and additional information services. Along the same lines, Kim and Eom (2002) used a 27 -item survey to gauge perceived satisfaction of online retail shopping. Their scale items included attributes related to physical retailing as well as those specifically relevant to online shopping. Using a sample of university students, they found that issues such as guaranteed on-time delivery and hassle-free return, and specified policies or explanations of these issues present on the website, affected online consumer satisfaction.

\section{Online Shopping Behaviors And Preferences}

Given the importance of understanding and predicting online shopping behaviors and preferences, numerous studies have focused on examining the influence of factors such as demographics (e.g., Sexton, Johnson and Hignite, 2002), attitudes toward the Internet (e.g., Rodgers and Harris, 2003), and shopping orientations (e.g., Girard, Korganonkar and Silverblatt, 2003). Particularly relevant to this research are studies that take into consideration the type of products purchased via the Internet and online shopping frequency.

Nelson (1970), within the context of advertising, originally classified product types into two categories, search and experience. Search products are those for which consumers can determine full information about dominant attributes "before purchasing" the product (e.g., books). Experience products are those for which dominant attributes cannot be determined prior to purchase (e.g., clothing). Later, Kline (1998) further distinguished experience products as those for which full information on dominant attributes cannot be known without direct experience or searching for information on dominant attributes is more costly / difficult than direct product experience (Kline, 1998, p. 199). A third category, credence products, was added by Darby and Karni (1973). Credence products are those for which it is difficult for consumers to verify the quality of dominant attributes even after purchasing or even using the product because they lack the requisite knowledge to do so (e.g., vitamins).

Brown, Pope and Voges (2003) investigated what factors influence consumers' stated intentions to purchase products on the Internet. They considered shopping orientation (personalizing, recreational, economic, communityoriented, apathetic and involved), prior purchase via the Internet, gender and product type. Six products representing varying degrees of search, experience and credence attributes were included in their study (clothing, travel, automobile, insurance, sporting equipment, entertainment tickets). Their findings indicate that product type, along 
with prior purchase and to a lesser extent gender, are more likely to affect online purchase intention than shopping orientation. Moreover, they found a significant interaction effect due to product type and gender.

Along this line of research, Girard, Korgaonkar and Silverblatt (2003) postulated that the relationships between shopping orientations (price consciousness, risk aversion, innovativeness, brand-consciousness, importance of convenience, variety-seeking inclination, impulsiveness) and demographics with purchase preferences on the Internet will differ by product type. Using a regional sample of consumers from the southeastern U.S., they found that shopping orientations do influence preferences for shopping from different types of retailers, including the Internet. Furthermore, they too found a relationship between gender and product type: males were more likely to purchase search products online whereas females were more likely to purchase experience products. Rodgers and Harris (2003), in investigating the role of gender on e-commerce, examined issues of emotion, trust and convenience in predicting satisfaction with online shopping as well as actual shopping behavior. Their study found that men consider online shopping more practical, convenient and satisfying compared to women. On the other hand, women were less trusting of e-commerce relative to men. Interestingly, the authors explain these differences in perceptions by taking product type into account. They note that men tend to shop for products that require less time, energy and emotional involvement (such as CD's and magazines) compared to women who tend to shop for more emotionally laden products (such as clothing and perfume).

In line with the research questions being addressed in our study, Girard, Silverblatt and Korgaonkar (2002) examined how product type affects online shopping preferences and the importance consumers place on various Internet retailers' attributes. Their study involved two phases. In the first phase, responses from graduate students were used to generate two specific products for each of the four product categories being considered (search, experience-1, experience- 2 and credence). In the second phase, data were collected from a regional sample of Internet shoppers via a telephone survey. Respondents were asked to state their preferences for purchasing various products (those identified in the first phase) online. In addition, they were asked to rate the importance of a set of internet retailer attributes assuming that they were purchasing one of the pre-identified products. They found that consumers' preferences for shopping online did vary by product type, with the most preferred type being search products and the least being experience- 2 products. Moreover, they found that product type did influence consumers' perceptions about Internet retailer attributes. Specifically, significant differences in the importance for two composite attributes, perceived value and merchandise assortment, were found among consumers grouped by product type.

\section{E-Quality Framework For Internet Shopping}

As part of our ongoing research in this area, we have developed a comprehensive set of factors that directly relate to the quality of Internet shopping. Our framework is organized along the four phases of a consumer's online shopping experience: (1) encountering the online retailer's homepage; (2) selecting a product from the online catalog; (3) completing the order form; and (4) accessing customer service and support. Our factors not only represent many of the e-quality dimensions cited in the literature, but they are expressed in concrete rather than conceptual terms. Consequently, they are both objective and measurable. Indeed, our factors have already been used to benchmark the homepages of Fortune 500 companies as well as conduct real online transactions for a sample of 55 web retailers (Tamimi, Rajan and Sebastianelli; 2000, 2003).

We identify the following twelve factors related to the quality of a consumer's experience as they encounter an online retailer's homepage.

- $\quad$ Meta tags - website easily found by search engines.

- $\quad$ Home page title - meaningful and easily recognizable.

- Domain name - unique and memorable.

- $\quad$ Speed of loading - time it takes to download.

- $\quad$ Links - number of bad links.

- $\quad$ Contact information - visible and easily accessible from homepage.

- $\quad$ Timeliness of information - includes date of last update.

- $\quad$ Privacy policies - explicit explanation on homepage. 
- $\quad$ Search engines - present on homepage for quickly finding relevant information.

- $\quad$ Translation to multiple languages - ability to translate content of the website into multiple languages.

- $\quad$ Navigational bars or site maps - present on homepage for ease of use.

- Value added extra content - such as product reviews, free samples, contests, and/or online communities.

In the next phase, selecting a product from the online catalog, a web retailer must provide its customers with sufficient realism in order to compensate for the inability to physically experience the product offerings. With this in mind, we identify the following seven factors affecting the quality of an online product catalog.

- $\quad$ Presence of product search engine - allow searching for products by category, price range or size.

- $\quad$ Price - adjacent to the product in the catalog.

- $\quad$ Images - presence of clear color images of product offerings.

- $\quad$ Comprehensive product descriptions - include size, dimension, weight, etc.

- $\quad$ Labeling of out of stock items - clear and easy to find.

- $\quad$ Brands and models - a wide variety offered.

- $\quad$ Special offers - coupons and discounts offered in product catalog.

After selecting a product to buy, an online shopper encounters an order form, typically integrated with an online shopping cart. Security and trust issues come to the forefront during this phase of a consumer's online shopping experience. We identify the following eight factors associated with the quality of completing an online order form.

- $\quad$ Breakdown of overall costs - includes shipping charges and sales tax.

- $\quad$ Multiple payment options - availability of various methods of payment.

- $\quad$ Shopping cart editing - ability to add and remove items from the cart.

- $\quad$ Security - presence of seals of approval logos or encryption technologies.

- $\quad$ Shipping options - availability of several options.

- Instructions - helpful in completing the order form.

- $\quad$ Ease of transaction - minimum number of clicks required to complete.

- $\quad$ Price calculation - correct and accurate.

Finally, the online shopping experience does not end with the completion of an order form. Customer service and support are critical determinants of satisfaction. For example, on-time delivery of product and hassle-free return have been found to influence online consumer satisfaction (Kim and Eom, 2002). Hence, we identify the following ten factors affecting the quality of customer service and support.

- Instant merchant notification - instant automated notification of order receipt.

- $\quad$ Order tracking - issuance of order tracking number for products purchased.

- $\quad$ On-time delivery - actual delivery matches promised delivery date.

- $\quad$ Honest product representation - product received matches online representation.

- $\quad$ Explicit return policy - clear explanation of return policy and restocking charges.

- $\quad$ Order cancellation - options for canceling orders already submitted.

- $\quad$ Order changes - options for changing the order already submitted.

- $\quad$ Product return - easy and hassle free.

- $\quad$ Customer help - available online help or toll free number.

- $\quad$ Accurate billing - actual bill is as expected and accurate.

While capturing many, if not all, of the e-quality dimensions discussed in the literature, this set of 37 factors is directly applicable to Internet shopping. 


\section{RESEARCH HYPOTHESES}

In this paper, we explore whether consumers' perceptions of internet retailer quality are affected by the frequency with which they shop online and the types of products they purchase. This is addressed within the context of a larger scale study designed to identify the underlying dimensions of e-tailing quality. E-tailing quality is operationalized using our framework of 37 factors organized along the four phases encountered by consumers shopping online: (1) retailer's home page, (2) online product catalog, (2) order form and (4) customer service and support. Based upon our review of related literature, we propose and test the following hypotheses:

H1: Frequent and infrequent online shoppers will differ in their perceptions of the importance of various e-tailing quality dimensions.

H2: Consumers' perceptions of the importance of various e-tailing quality dimensions will differ based on the type of products they purchase online.

\section{METHODOLOGY}

\section{Sample}

Our national sample consisted of Internet shoppers defined as those who are engaged in buying products and services online. The sampling frame, consisting of opt-in e-mails, was obtained from Martin Worldwide (www.MartinWorldwide.net), a provider for direct mail and telemarketing leads. The link to the web survey was sent via e-mail to 6666 online consumers from their listing. Only one e-mail was sent to each consumer. In order to increase study participation, an incentive lottery was offered. Those who completed the survey would have their names entered into a lottery awarding a total of four cash prizes. Data were collected during the spring of 2004.

\section{Survey Instrument}

The on-line questionnaire consisted of three sections, two of which are relevant for this paper. The first gathered background information on online shopping behaviors and preferences (e.g., types of products and/or services purchased) and demographics (e.g., gender, age, etc.). The second section consisted of 37 statements that represented all of the e-quality factors associated with the four phases of online shopping. The statements were randomly ordered on the questionnaire (and not grouped according to phase). Respondents were asked to rate how important each factor was in determining the quality of an online retailer using a five-point scale $(1=$ not important, 2 = slightly important, $3=$ somewhat important, $4=$ important, $5=$ very important).

\section{Data Analysis}

Principal components factor analysis was used to determine whether the observed correlations among the 37 items representing the e-quality factors could be explained by the existence of a smaller number of underlying equality dimensions. Only factors that accounted for a variance greater than one (that is eigenvalues $>1$ ) were extracted. Varimax rotation, an algorithm that minimizes the number of variables that have high loadings on the orthogonal factors, was used to improve interpretability. Factor scores from the factor solution were analyzed to determine whether differences exist between consumers grouped on the basis of online shopping frequency and types of products purchased online.

\section{RESULTS}

\section{Respondent Profile}

A total of 422 respondents completed the online survey for a response rate of $6.3 \%$. Of those responding, the majority is Caucasian (73\%), employed full-time (62\%), female (59\%) and married (57\%). The average age is 44 , with $31 \%$ falling in the 36 to 45 age group (33\% are between 46 and 55). Of those employed either full or part time, $24 \%$ report holding executive / managerial / administrative positions while $23 \%$ are technical / clerical (25\% selected 
the other category). In terms of education level, the largest percentage (35\%) indicates that they have completed some college. About a quarter (23\%) of the respondents has earned bachelor's degrees. While the majority (59\%) has an annual household income of less than $\$ 50,000,21 \%$ report an annual household income greater than $\$ 75,000$.

In terms of online behaviors, $23 \%$ of our respondents indicate that they had made at least 10 purchases online during the last six months; the largest percentage (31\%) report making one to three purchases via the Internet during this same period. The vast majority (77\%) has been using the Internet for over four years, and $43 \%$ report browsing the web daily. Respondents were also given a list of products/services and asked to indicate those that they had purchased online within the last six months. Those that had been purchased online by at least $25 \%$ of our respondents include books / magazines (43\%), apparel / clothing (37\%), DVD's and videos (32\%), computer hardware or software $(29 \%)$, music $(25 \%)$ and travel $(25 \%)$.

\section{Factor Analysis}

In order to exploit the intercorrelations among the 37 items representing measures of e-tailing quality, factor analysis was performed to identify the underlying dimensions. Seven factors were extracted that accounted for about 58 percent of the total variation in the observed importance ratings. Figure 1 shows the items that loaded strongly on each of the seven factors. In developing this factor solution, items with loadings less than .35 (after varimax rotation) were dropped. Under each factor the items are listed in descending order according the magnitude of their loading.

The seven dimensions extracted are reliability, accessibility, ordering services, convenience, product content, assurance and credibility. As is typical, we labeled these dimensions based on the specific items that loaded on each factor. Moreover, these e-tailing quality dimensions are congruent with those proposed by other researchers (e.g., Madu and Madu, 2002). In order to assess the internal consistency of these derived factors, Chronbach's alpha was computed as a measure of reliability. Although the generally acceptable minimum alpha is usually 0.70 , Nunnally (1978) suggests that allowing a somewhat lower threshold, such as 0.60 or even 0.50 , for exploratory work involving the use of newly developed scales. Reliability analysis results are included in Figure 1. All factors had a Chronbach's alpha greater than 0.65 .

Figure 1

Factor Solution: Items Loading On Each Factor

Factor I - "Reliability" (Chronbach's alpha $=.857)$

- $\quad$ Accurate calculation of total price when ordering.

- $\quad$ Accurate billing.

- $\quad$ Ability to add and remove items from the shopping cart.

- $\quad$ A breakdown of overall cost that includes price of product, shipping charges and applicable sales tax.

- $\quad$ Price displayed adjacent to the product in the catalog.

- $\quad$ Labeling of items that are out of stock.

- $\quad$ Issuance of order tracking numbers.

- $\quad$ On time delivery of order.

Factor II - “Accessibility” (Chronbach's alpha $=.843)$

- $\quad$ Ability to translate website information into multiple languages.

- Unique trademark or other name that makes promotions and commercial offerings easy to remember.

- $\quad$ A meaningful homepage title.

- $\quad$ Search engines present on homepage to help find relevant information.

- $\quad$ Retailer website easily found by search engines.

- $\quad$ Presence of navigational bars or site maps.

- $\quad$ Timely information updates on homepage. 
Factor III - “Ordering Services" (Chronbach's alpha $=.825)$

- $\quad$ Options for canceling an order.

- $\quad$ Ability to change an order that has already been submitted.

- Availability of different shipping options.

- $\quad$ Issuance of instant automated merchant notification of order received.

- $\quad$ Presence of instructions for completing the order form.

- $\quad$ Availability of several payment options, such as credit card, check or phone order.

Factor IV - "Convenience" (Chronbach's alpha $=.783)$

- $\quad$ Special offers such as coupons and discounts in the online catalog.

- $\quad$ Value added extras on the homepage such as product reviews, contests, etc.

- $\quad$ Presence of search engines in the online catalog that allow searching for products by category, price range, size.

- $\quad$ Speed of page downloading.

- $\quad$ Order form is completed with minimum number of clicks.

Factor V - "Product Content" (Chronbach's alpha $=.670)$

- $\quad$ Display of color images of products.

- $\quad$ Providing product descriptions (e.g., size dimensions, color, weight, etc.)

- $\quad$ A wide variety of brands and models offered.

Factor VI - “Assurance" (Chronbach's alpha $=.659)$

- Inclusion of privacy policies on the homepage.

- $\quad$ Availability of online help or toll free number.

- $\quad$ No bad links.

- $\quad$ Security of orders (e.g., presence of seals of approval logos).

Factor VII - “Credibility” (Chronbach's alpha $=.766)$

- $\quad$ Presence of information regarding return policy and restocking charges.

- $\quad$ Presence of contact information on homepage.

- $\quad$ Accuracy of online product representations.

- Hassle free product return.

\section{Hypothesis Testing}

In order to test whether frequent and infrequent online shoppers differed in their perceptions regarding internet retailer quality, we grouped respondents based on the number of online purchases they reported making in the last six months. The response categories were none, 1-3, 4-6, 7-9 and 10 or more. We eliminated respondents who fell in the middle category. Consequently, group 1 consisted of those who made 3 or fewer online purchases (infrequent online shoppers) and group 2 was comprised of those who made 7 or more online purchases (frequent online shoppers). We tested for significant differences in the importance placed on the seven e-tailing quality dimensions between groups using the independent t-test for two means. Factor scores from the factor solution were analyzed. These results are presented in Table 1.

Similarly, we grouped respondents according to product type in order to examine its potential effect on their perceptions of the importance of the seven e-tailing quality dimensions. In this case we used respondents' answers to the open-ended question "which product or service are you most likely to purchase online?" This open-ended question generated a wide range of responses, which we categorized into one of the three product types: search, experience, and credence. We based our categorizations on the scheme provided by Girard, Silverblatt and Korgaonkar (2002) except we did not distinguish between experience-1 and experience-2 products. Responses that could not be readily categorized were eliminated. Figure 2 shows the specific items included for each product type. 
We used ANOVA (analysis of variance) to test for the effect of product type on each of the seven e-tailing quality dimensions. Again, factor scores from the factor solution were analyzed. Because the number of respondents using the Internet to purchase credence products is much smaller than the number purchasing search or experience products, we also used the t-test to explore differences between the two latter groups. Moreover, identifying credence items is less straightforward than identifying search or experience products. In addition, studies reported in the literature have often concentrated on only search and experience products (e.g., Rodgers and Harris, 2003). These results are reported in Table 2.

Finally, we performed a Chi Square test for independence to determine whether a relationship exists between the frequency of online purchasing and product type. Our results, Chi-square $=2.073$, $p$-value $=0.718$, indicate that these variables are independent and we can therefore analyze their potential effects on respondents' perceptions of internet retailer quality separately.

Table 1

T-Test Results For Online Shopping Frequency

\begin{tabular}{|c|c|c|c|c|}
\hline $\begin{array}{l}\text { E-Retailing } \\
\text { Dimension }\end{array}$ & Groups & Mean Score * & t-stat. & p-value \\
\hline \multirow[t]{2}{*}{ Reliability } & $\begin{array}{l}\text { Infrequent Shoppers } \\
(\mathrm{n}=145)\end{array}$ & -.183 & -2.232 & .027 \\
\hline & $\begin{array}{l}\text { Frequent Shoppers } \\
(\mathrm{n}=127)\end{array}$ & .096 & & \\
\hline \multirow[t]{2}{*}{ Accessibility } & $\begin{array}{l}\text { Infrequent Shoppers } \\
(\mathrm{n}=145)\end{array}$ & .054 & .859 & .391 \\
\hline & $\begin{array}{l}\text { Frequent Shoppers } \\
(\mathrm{n}=127)\end{array}$ & -.054 & & \\
\hline \multirow[t]{2}{*}{ Ordering Services } & $\begin{array}{l}\text { Infrequent Shoppers } \\
(\mathrm{n}=145)\end{array}$ & .139 & 2.014 & .045 \\
\hline & $\begin{array}{l}\text { Frequent Shoppers } \\
(\mathrm{n}=127)\end{array}$ & -.110 & & \\
\hline \multirow[t]{2}{*}{ Convenience } & $\begin{array}{l}\text { Infrequent Shoppers } \\
(\mathrm{n}=145)\end{array}$ & -.081 & -1.788 & .075 \\
\hline & $\begin{array}{c}\text { Frequent Shoppers } \\
(\mathrm{n}=127)\end{array}$ & .147 & & \\
\hline \multirow[t]{2}{*}{ Product Content } & $\begin{array}{l}\text { Infrequent Shoppers } \\
(\mathrm{n}=145)\end{array}$ & -.121 & -2.218 & .027 \\
\hline & $\begin{array}{c}\text { Frequent Shoppers } \\
(\mathrm{n}=127)\end{array}$ & .145 & & \\
\hline \multirow[t]{2}{*}{ Assurance } & $\begin{array}{l}\text { Infrequent Shoppers } \\
(\mathrm{n}=145)\end{array}$ & .088 & 1.219 & .224 \\
\hline & $\begin{array}{l}\text { Frequent Shoppers } \\
(\mathrm{n}=127)\end{array}$ & -.063 & & \\
\hline \multirow[t]{2}{*}{ Credibility } & $\begin{array}{l}\text { Infrequent Shoppers } \\
(\mathrm{n}=145)\end{array}$ & .090 & 1.003 & .317 \\
\hline & $\begin{array}{l}\text { Frequent Shoppers } \\
(\mathrm{n}=127)\end{array}$ & -.033 & & \\
\hline
\end{tabular}

* Means are computed for standardized factor scores.

Figure 2

\section{Responses In Each Product Category}

\begin{tabular}{ll}
\hline Search: & books, magazines, computer software, computer hardware, DVD's, magazines, music, office supplies, video \\
& games. \\
Experience: & apparel, beauty products, clothing, gifts, handbags, herbs, home décor, jewelry, shoes. \\
Credence: & airline tickets, health, prescriptions, travel, vitamins. \\
\hline
\end{tabular}


Table 2

T-Test Results For Product Type

\begin{tabular}{|c|c|c|c|c|}
\hline $\begin{array}{l}\text { E-Retailing } \\
\text { Dimension }\end{array}$ & Groups & Mean Score * & t-stat. & p-value \\
\hline \multirow[t]{2}{*}{ Reliability } & $\begin{array}{c}\text { Search } \\
(\mathrm{n}=129)\end{array}$ & .132 & 1.135 & .258 \\
\hline & $\begin{array}{c}\text { Experience } \\
(\mathrm{n}=86)\end{array}$ & -.026 & & \\
\hline \multirow[t]{2}{*}{ Accessibility } & $\begin{array}{c}\text { Search } \\
(\mathrm{n}=129)\end{array}$ & .026 & .405 & .686 \\
\hline & $\begin{array}{c}\text { Experience } \\
(\mathrm{n}=86)\end{array}$ & -.030 & & \\
\hline \multirow[t]{2}{*}{ Ordering Services } & $\begin{array}{c}\text { Search } \\
(\mathrm{n}=129)\end{array}$ & -.101 & -2.039 & .043 \\
\hline & $\begin{array}{c}\text { Experience } \\
(\mathrm{n}=86)\end{array}$ & .149 & & \\
\hline \multirow[t]{2}{*}{ Convenience } & $\begin{array}{c}\text { Search } \\
(\mathrm{n}=129)\end{array}$ & -.113 & -1.494 & .137 \\
\hline & $\begin{array}{c}\text { Experience } \\
(\mathrm{n}=86)\end{array}$ & .100 & & \\
\hline \multirow[t]{2}{*}{ Product Content } & $\begin{array}{c}\text { Search } \\
(\mathrm{n}=129)\end{array}$ & -.174 & -2.572 & .011 \\
\hline & $\begin{array}{c}\text { Experience } \\
(n=86)\end{array}$ & .197 & & \\
\hline \multirow[t]{2}{*}{ Assurance } & $\begin{array}{c}\text { Search } \\
(\mathrm{n}=129)\end{array}$ & -.153 & -1.109 & .269 \\
\hline & $\begin{array}{c}\text { Experience } \\
(\mathrm{n}=86)\end{array}$ & .006 & & \\
\hline \multirow[t]{2}{*}{ Credibility } & $\begin{array}{c}\text { Search } \\
(\mathrm{n}=129)\end{array}$ & -.011 & .143 & .886 \\
\hline & $\begin{array}{c}\text { Experience } \\
(\mathrm{n}=86)\end{array}$ & -.031 & & \\
\hline
\end{tabular}

* Means are computed for standardized factor scores

Based on the results presented in Tables 1 and 2, we find some empirical support for our hypotheses. With regard to online shopping frequency, we see that statistically significant differences exist between infrequent and frequent shoppers for three of the seven e-tailing quality dimensions (at the .05 level of significance). Infrequent online shoppers place significantly more importance on ordering services; frequent online shoppers consider reliability and product content to be significantly more important than infrequent shoppers. Given that infrequent shoppers have less experience purchasing online, it seems reasonable that they would want maximum flexibility when ordering (ability to change and/or cancel orders) as well as instructions for completion and notification of order receipt. On the other hand, frequent online shoppers with more experience are not as concerned about the ordering process. Rather, their focus is on reliable pricing (accurate calculation and billing) as well as on-time delivery and order tracking capabilities. In addition, they consider product selection and the presentation of product information important e-tailing quality attributes.

With regard to product type, we performed analysis of variance to determine its potential effect on consumers' perceptions. We found a significant effect on only one e-tailing quality dimension: product content $(F=$ 3.434, $p=.034)$. Post hoc analysis revealed that those who purchased experience products online considered this dimension to be significantly more important than those who purchased either search or credence products; there was no significant difference between the latter two groups. For the reasons cited above, we then restricted attention to differences that might exist between online consumers who purchase search versus experience products (see t-test results in Table 2). In doing so, we found that these two groups also differed in their perceptions about ordering services, this dimension being more important to those purchasing experience products. Given that the purchase 
decisions for experience products are more complex than for search products, and generally require more time and involvement, it is not surprising that those purchasing experience products online would be more concerned with having sufficient product information as well as flexibility in the ordering process.

\section{DISCUSSION AND IMPLICATIONS}

Our findings suggest that both online shopping frequency and type of product have some effect on how consumers view online retailer quality dimensions. In particular, the frequency with which consumers shop online affects their perceptions about reliability, ordering services and product content; the type of products they purchase affects their perceptions about ordering services and product content. Our findings agree somewhat with previous research in this area. For instance, Girard, et. al. (2002) found that consumers prefer to purchase search over experience products online. That is also true for our sample of respondents. Moreover, they found that product type had a significant effect on two online retailer attributes: perceived value and merchandise assortment. Merchandise assortment corresponds to our dimension product content.

Our study adds to those already reported in the literature in several significant ways. First, we use a national rather than regional (or student) sample of online consumers. Second, we use actual behavior rather than a hypothetical scenario to segment online consumers by product type. In the Girard et. al. (2002) study, respondents were asked to rate the importance of various online retailers' attributes assuming that they were going to purchase a specific type of product (search, experience or credence). In contrast, we segment our respondents based on the type of product they are likely to purchase online. Finally, we examine online consumers' perceptions about dimensions related to internet retailer quality that are empirically derived from items that have already been used to benchmark websites. From a research perspective, this contributes to the area of scale development. From a practical perspective, our results are useful for retailers interested in improving the quality of their online experience.

\section{REFERENCES}

1. Brown, M., Pope, N., and Voges, K. (2003), Buying or browsing? An exploration of shopping orientations and online purchase intention, European Journal of Marketing, Vol. 37 No. 11/12, pp. 1666-1684.

2. Cho, N. and Park, S. (2002), Development of electronic commerce user-consumer satisfaction index (ECUSI) for Internet shopping, Industrial Management and Data Systems, Vol. 101 No. 8, pp. 400-5.

3. Cox, J. and Dale, B.G. (2001), Service quality and e-commerce: an exploratory analysis, Managing Service Quality, Vol. 11 No. 2, pp. 121-31.

4. Cronin, J.J. and Taylor, S.A. (1992), Measuring service quality: a reexamination and extension, Journal of Marketing, Vol. 56, pp. 55-68.

5. Darby, M.R. and Karni, E. (1973), Free competition and the optimal amount of fraud, Journal of Law and Economics, Vol. 16 (April), pp. 67-86.

6. Deming, W.E. (1986), Out of the crisis. Cambridge, MA: MIT Center for Advanced Engineering Study.

7. Girard, T., Silverblatt, R., and Korgaonkar, P. (2002), Influence of product class on preference for shopping on the internet, Journal of Computer Mediated Communication, Vol. 8 No. 1, 22 p.

8. Girard, T., Korgaonkar, P., and Silverblatt, R. (2003), Relationship of type of product, shopping orientations, and demographics with preference for shopping on the Internet, Journal of Business and Psychology, Vol. 18 No. 1, pp. 101-120.

9. Kim, E.B. and Eom, S.B. (2002), Designing effective cyber store user interface, Industrial Management and Data Systems, Vol. 102 No. 5, pp. 241-51.

10. Klein, L.R. (1998), Evaluating the potential of interactive media through a new lens: search versus experience goods, Journal of Business Research, Vol. 41, pp. 195-203.

11. Madu, C.N. and Madu, A.A. (2002), Dimensions of e-quality, International Journal of Quality \& Reliability Management, Vol. 19 No. 3, pp. 246-58.

12. Nelson, P. (1970), Information and consumer behavior, Journal of Political Economy, Vol. 78 No. 2, pp. 311-329.

13. Nunnally, J. (1978), Psychometric theory. New York: McGraw Hill. 
14. Rodgers, S. and Harris, M.A. (2003), Gender and e-commerce: an exploratory study, Journal of Advertising Research, September, pp. 322-329.

15. Sexton, R.S., Johnson, R.A., and Hignite, M.A. (2002), Predicting Internet / e-commerce use, Internet Research: Electronic Networking, Applications and Policy, Vol. 2 No. 5, pp. 402-410.

16. Shop.org (2006), Statistics available at: www.shop.org/learn/stats.html (accessed May).

17. Tamimi, N., Rajan, M., and Sebastianelli, R. (2000), Benchmarking the home pages of Fortune 500 companies, Quality Progress, Vol. 33 No. 7, pp. 47-51.

18. Tamimi, N., Rajan, M., and Sebastianelli, R. (2003), The state of online retailing, Internet Research: Electronic Networking, Applications and Policy, Vol. 13 No. 3, pp. 146-155.

\section{NOTES}




\section{NOTES}

